\title{
Uric acid and serum lipids in cerebrovascular disease
}

\author{
Part 2: Uric acid-plasma lipid correlations
}

JOHN PEARCE AND HASAN AZIZ

From the Combined Neurological Service, Hull Royal Infirmary

A significant proportion of patients suffering from atherosclerotic coronary artery disease have elevated levels of lipid fractions in the blood (Schrade, Boehle, and Biegler, 1960; Albrink, Meigs, and Man, 1961; Albrink, 1962). Similar observations in patients with cerebrovascular disease have been sparse, and have yielded conflicting results. Of studies measuring serum cholesterol, Heyman, Nefzger, and Estes (1961) showed significantly higher cholesterol levels in patients with cerebral infarction than in patients with 'non-atherosclerotic illnesses'. Robinson, Higano, and Cohen (1963) described higher $\beta$ lipoprotein cholesterol concentrations and $\beta: \alpha$ lipoprotein ratios in patients with cerebral thrombosis than in matched controls. However, others have failed to demonstrate significant elevation of serum cholesterol in cerebral thrombosis (Meyer, Waltz, Hess, and Zak, 1959).

Considering other serum lipids, Katsuki, Uzawa, Fujimi, Shiratsuchi, and Ito (1964) reported significantly higher triglyceride concentrations in patients with cerebrovascular disease than in normal controls. Feldman and Albrink (1964) studied 63 male patients, aged 37 to 73 , with transient ischaemic attacks and with completed strokes. They found serum concentrations of cholesterol and triglycerides to be increased. The elevated triglyceride concentration was more closely associated with cerebrovascular disease than was the serum cholesterol concentration. Furthermore, a relatively highserum cholesterol was usually not associated with cerebrovascular disease unless the triglyceride was also elevated, while a low serum cholesterol concentration could be associated with cerebrovascular disease if the triglyceride was increased. This finding of a relationship between serum triglycerides and strokes, but less striking correlation with other lipid fractions, is in agreement with the findings of Katsuki $e t$ al. (1964) in Japanese subjects.

In a related study (Pearce and Aziz, 1969), we have been able to show that about $25 \%$ of patients suffering from strokes have hyperuricaemia. This $\frac{\mathbb{}}{\overparen{2}}$ accords with the known predisposition to athero- ${ }^{\infty}$ sclerosis observed in subjects suffering from gout $\vec{O}$ (Bauer and Klemperer, 1947). Gertler, Garn, and $\overrightarrow{-}$ Levine (1951) have shown that there is some re- ${ }_{0}$ lationship between serum cholesterol, lipid phosphorus, and uric acid in determining the occurrence of coronary artery disease. They were able to $\omega_{j}$ produce a simple formula relating these three $\overrightarrow{-}$ fractions, and they produced an index (uric acidi $\infty_{\infty}^{\infty}$ ratio) incorporating these observations which wass effective in separating the coronary heart disea group from control subjects in $94 \%$ of cases.

Against this background, the present study wo designed to investigate the relationship of plasngac uric acid and various lipid fractions in patients wi cerebrovascular disease. The index mention above has been applied to these patients, and the values obtained for the various lipid fractions. have been subjected to a statistical analysis, applying correlation coefficients calculated by a computer.

\section{MATERIAL AND METHODS}

Sixty subjects, of whom 42 were male and 18 were female, $\overrightarrow{\vec{F}}$ formed the basis for this study. The patients had been윽 admitted for neurological study on account of an acute cerebrovascular incident, which was ultimately diagnosed as a cerebral infarct $(95 \%)$ or cerebral haemorrhage $(5 \%)$. These patients were included in the separately reported study of uric acid levels in cerebrovascular disease (Pearce and Aziz, 1969). Venous blood was: taken in the fasting state, 12 hours after the last meal, at 9.0 a.m., in all subjects. Uric acid levels were estimated by the phosphotungstic sodium cyanide method; serum 3 cholesterol by the method of Pearson, Sterm, and Mackett (1953); serum free fatty acids by the method윽 of Peters and Van Slyke (1946); phospholipids as lipid phosphorus by the method of McDonald and Hallo (1957); serum triglycerides by the method of $\operatorname{Van}_{N}$ Handel, Zilversmit, and Bowman (1957). It is importanto to utilize a conservative range of normal values, in N attempting to detect abnormalities of plasma lipids, N్ 
since these fractions are affected by such a wide variety of physiological, dietetic, and racial variations.

The following values were taken to represent the upper limit of normal in the fasting state for the age group investigated (mean age for both sexes, 60.6, S.D., 11·2):

Serum uric acid: $6 \mathrm{mg} / 100 \mathrm{ml}$. in females

Serum uric acid: $7 \mathrm{mg} / 100 \mathrm{ml}$. in males

Serum cholesterol: $300 \mathrm{mg} / 100 \mathrm{ml}$. in females

Serum cholesterol: $270 \mathrm{mg} / 100 \mathrm{ml}$. in males

Serum free fatty acids: $450 \mathrm{mg} / 100 \mathrm{ml}$. (male and female)

Serum triglycerides: $180 \mathrm{mg} / 100 \mathrm{ml}$. (male and female)

Serum phospholipids: $320 \mathrm{mg} / 100 \mathrm{ml}$. (male and female)

These figures were derived from the literature describing the methods cited above, and from current epidemiological data (Oliver, 1968).

\section{RESULTS}

The total sample consisted of 60 subjects (41 male and 19 female). The males and females were compared on all variables and were found to differ significantly in age alone (mean ages: males $57 \cdot 4$ years, females 67.6 years, $P<0.001$ by $t$ test). Since sex and age were found to be unrelated $(P>>0.05)$ to the lipid fractions considered in this study, it was appropriate to pool the data for both sexes in all further statistical analyses. The age range under investigation was small (mean age: 60.6 years for both sexes; S.D. 11.2), and this probably explains the absence of any obvious increase in higher levels which are known to accompany increasing age. With respect to sex differences, the females are significantly older than the males, and this factor probably obscures any sex difference in lipid levels at any particular age group. Means and S.D. of variables other than age are shown in Table 1.

In order to assess whether these results were different from those expected in normal subjects, estimates of the 95th percentile level for normals for each fraction were made. The percentage of
TABLE 1

MEANS AND STANDARD DEVIATIONS OF URIC ACID AND LIPID FRACTIONS IN SERUM

\begin{tabular}{lcc}
\hline & $\begin{array}{c}\text { Mean } \\
(\mathrm{mg} / 100 \mathrm{ml} .)\end{array}$ & $\begin{array}{c}\text { Standard deviations } \\
(\mathrm{mg} / 100 \mathrm{ml} .)\end{array}$ \\
\cline { 2 - 3 } & 6.0 & $1 \cdot 7$ \\
Uric acid & 214 & $72 \cdot 6$ \\
Cholesterol & 138 & 76.4 \\
Triglycerides & 234 & 88.5 \\
Phospholipids & 443 & 206.2 \\
Free fatty acids & & \\
\hline
\end{tabular}

subjects in the sample having levels over the estimated normal 95th percentile was then compared with the estimated $5 \%$ of normals. Details of these comparisons are given in Table 2 , which shows that the percentage of subjects with high free fatty acid and triglycerides is very significantly above the expected $5 \%$. Therefore, it can be concluded that the subjects show raised levels of these two fractions; there are also elevations of all the lipid fractions in more than the expected $5 \%$ of subjects.

In assessing the relationship between hyperuricaemia and elevated lipid fractions, intercorrelations (Pearson's product moment) were calculated by a computer between uric acid levels and the lipid fractions. These are shown in Table 3 and indicate that, while all the lipid fractions intercorrelate significantly - that is, a subject who has one high value tends to have high values for other fractionsuric acid fails to correlate to a significant degree with cholesterol, phospholipids, and free fatty acids. The correlation of 0.23 between uric acid and triglycerides just fails to reach the statistically accepted level of $P=0.05$ (for this correlation, $0.10>P>0.05$ in a two-tailed test). This result may have clinical and pathological significance.

The uric acid ratio (Gertler et al., 1951) is represented by:

$\mathbf{k}=\frac{\text { cholesterol }(\mathrm{mg} / 100 \mathrm{ml} .) \times \text { uric acid }(\mathrm{mg} / 100 \mathrm{ml} .)}{\text { lipid phosphorus }(\mathrm{mg} / 100 \mathrm{ml} .)}$

$\mathrm{k}=$ less than 119 in $94 \%$ of normal subjects (146 observations).

TABLE 2

ASSESSMENT OF ELEVATION OF SERUM LIPID FRACTIONS

\begin{tabular}{|c|c|c|c|c|c|}
\hline Fraction & $\begin{array}{l}\text { Estimated upper limit of normal, } \\
\text { 95th percentile }\end{array}$ & $(\operatorname{sex})$ & $\begin{array}{l}\text { Patients above } 95 \text { th } p \\
\text { (no.) }\end{array}$ & $\begin{array}{l}\text { percentile } \\
(\%)\end{array}$ & Significance \\
\hline $\begin{array}{l}\text { Cholesterol } \\
\text { Cholesterol } \\
\text { Free fatty acids } \\
\text { Triglycerides } \\
\text { Phospholipids } \\
\text { Uric acid } \\
\text { Uric acid }\end{array}$ & $\begin{array}{c}270 \mathrm{mg} / 100 \mathrm{ml} . \\
300 \mathrm{mg} / 100 \mathrm{ml} . \\
450 \mathrm{mg} / 100 \mathrm{ml} . \\
180 \mathrm{mg} / 100 \mathrm{ml} . \\
320 \mathrm{mg} / 100 \mathrm{ml} . \\
7.0 \mathrm{mg} \\
6.0 \mathrm{mg}\end{array}$ & $\begin{array}{c}\mathbf{M} \\
\mathbf{F} \\
\mathbf{M} \text { and } \mathbf{F} \\
\mathbf{M} \text { and } \mathbf{F} \\
\mathbf{M} \text { and } \mathbf{F} \\
\mathbf{M} \\
\mathbf{F}\end{array}$ & $\begin{array}{r}6 \\
2 \\
21 \\
15 \\
7 \\
9 \\
6\end{array}$ & $\begin{array}{l}15 \\
10 \cdot 5 \\
35 \\
25 \\
11 \cdot 6 \\
20 \\
33\end{array}$ & $\begin{array}{c}\text { N.S. } \\
\text { N.S. } \\
\mathbf{P}<0.001 \\
\mathbf{P}<0.001 \\
\text { N.S. }\end{array}$ \\
\hline
\end{tabular}


Our results applying this formula are as follows:

60 observations, Mean $k=143.4$ (S.D., $81 \cdot 1$ )

Range $38 \cdot 1$ to $361 \cdot 7$

Using $\mathbf{k}=119$ as the cut off point, 30 subjects were above and 30 below this figure.

\section{DISCUSSION}

The results indicate that the patients in this study with cerebrovascular disease had serum lipid levels which were consistently higher than those anticipated in the normal population. The magnitude of this elevation was of a moderate degree, and was noted particularly in respect of serum triglycerides and free fatty acids (Table 4). The results extend the observations of Heyman et al. (1961), Feldman and Albrink (1964), Katsuki et al. (1964), and Jakobson (1967).

It is important to note, however, that attacks of cerebral ischaemia and cerebral infarction may occur in the presence of normal serum lipid levels as pointed out by Meyer et al. (1959). Inspection of our results, and consideration of the previous studies cited, show a general trend in which an elevated serum triglyceride concentration is more closely associated with cerebrovascular disease than are elevations of other serum lipid fractions. In general, these findings are similar to those observed in coronary artery disease although they are less marked (Albrink et al., 1961).
The various lipid fractions estimated in this $Z$ study are transported in lipoprotein molecules. $\stackrel{\Phi}{\subseteq}$ The $\alpha$-lipoproteins are of high density, and are rich in phospholipids. The present investigation does not show any gross abnormality of $\alpha$-lipoprotein metabolism. The $\beta$-lipoproteins are of low density, and largely represented by cholesterol. The very low density $\beta$-lipoproteins are reflected in triglyceride levels in the serum. Our results show predominant changes in the $\beta$-lipoprotein fractions $\Rightarrow$ of both low density and very low density. However, $\stackrel{?}{+}$ these are not of the magnitude seen in the genetically? determined hyperlipoproteinaemic states described by Fredrickson, Levy, and Lees (1967).

The main purpose of this work was to assess the possibility of a correlation between plasma lipid fractions and hyperuricaemia. Theoretical reasons for such a relationship have been described in. a previous communication (Pearce and Aziz, $\vec{\omega}$ 1969). A clinical basis for such an association is ? provided by Harris-Jones (1957). He reported 223 patients and their relatives with essential hyper-? cholesterolaemia and xanthomatosis, and found $\omega$ that all except one of the patients with uric acid. levels of greater than $7 \mathrm{mg} / 100 \mathrm{ml}$. had serum $\infty$ cholesterol levels of $400 \mathrm{mg} / 100 \mathrm{ml}$. or more. 霡응 suggested that the conditions of hyperuricaem and hypercholesterolaemia might be related by genetic linkage, on the basis of an autosomalo dominant inheritance. He also considered the possibility that hypercholesterolaemia might inhiligt

TABLE 3

INTERCORRELATIONS OF URICACID AND LIPID FRACTIONS IN SERUM

\begin{tabular}{lccc}
\hline & Uric acid & Cholesterol & Triglycerides \\
\cline { 2 - 4 } Cholesterol & 0.066 & & Phospholipids \\
Triglycerides & 0.230 & $0.375 \dagger$ & $0.445 \dagger$ \\
Phospholipids & -0.002 & $0.284^{*}$ & $0.555 \dagger$ \\
Free fatty acids & 0.022 & $0.323^{*}$ & $0.456 \dagger$ \\
\hline
\end{tabular}

* Correlation significant at 0.05 level.

†Correlation significant at 0.01 level.

TABLE 4

CORRELATION COEFFICIENTS OF SERUM URIC ACID, LIPIDS AND 'URIC ACID RATIO'

\begin{tabular}{|c|c|c|c|c|c|c|}
\hline & Age & Uric acid & Cholesterol & Triglycerides & Phospholipids & $\begin{array}{c}\text { Free fatty } \\
\quad \text { acids }\end{array}$ \\
\hline $\begin{array}{l}\text { Uric acid } \\
\text { Cholesterol } \\
\text { Triglycerides } \\
\text { Phospholipids } \\
\text { Free fatty acids } \\
\text { Uric acid ratio }\end{array}$ & $\begin{array}{l}0.123 \\
0.195 \\
0.022 \\
0.069 \\
0.065 \\
0.163\end{array}$ & $\begin{array}{c}0.066 \\
0.230 \\
-0.002 \\
0.022 \\
0.515 \dagger\end{array}$ & $\begin{array}{l}0.375 \dagger \\
0.455 \dagger \\
0.284^{*} \\
0.374 \dagger\end{array}$ & $\begin{array}{r}0.555 t \\
0.323^{*} \\
-0.120\end{array}$ & $\begin{array}{r}0.456+ \\
-0.492 \dagger\end{array}$ & -0.047 \\
\hline
\end{tabular}

-Correlation significant at 0.05 level.

+Correlation significant at $\mathbf{0 . 0 1}$ level. 
the excretion of uric acid and hence produce hyperuricaemia.

Evaluation of our data by correlation coefficients, shows quite clearly that elevation of the lipid fractions intercorrelate to a significant level. However, uric acid levels do not correlate to a significant degree with free fatty acids, phospholipids, or cholesterol. The correlation coefficient between uric acid and triglyceride was 0.23 and has borderline statistical significance $0.10>P>0.05$. This observation may be clinically relevant.

On theoretical grounds, it would be valuable to obtain some biochemical parameter which would separate patients with cerebrovascular disease from control subjects of similar age, sex, and domestic background. Although never widely applied, the uric acid ratio (Gertler et al., 1951) seems to offer a simple formula of high predictive value in coronary artery disease, in which it separated $94 \%$ of patients from controls. This formula has never been applied to patients with cerebral ischaemic attacks or cerebral infarction. Its application in our series of patients showed a very wide range of values, and $50 \%$ of the subjects examined were above the critical figure of 119 and $50 \%$ were below. We concluded, therefore, that this formula has no value in either the prediction or detection of cerebrovascular disease, but we are unable to explain the discrepancy between this group of patients and those with coronary artery disease.

In conclusion, we have shown a general trend consisting of an elevation in serum lipid fractions in patients with cerebrovascular disease. The abnormalities observed were not, however, of gross magnitude. The serum lipid fraction showing the highest degree of correlation with the clinical occurrence of a stroke was the serum triglyceride level in the fasting state. A small degree of correlation below the statistically acceptable limits of significance was shown between hyperuricaemia and hypertriglyceridaemia. The role of these abnormalities in the genesis of atherosclerotic disease of the great vessels and cerebral vascular tree remains uncertain, but there is no definitive evidence that such abnormalities are primarily responsible for cerebrovascular atherosclerosis.

We are, therefore, unable to provide any scientific basis for dietetic restriction or cholesterol lowering drugs in the management of patients with cerebrovascular atherosclerosis.

SUMMARY Measurements of four plasma lipid fractions and uric acid have been performed in a series of patients with cerebrovascular disease. A modest elevation of the lipid fractions was noted, especially marked in respect of triglycerides. Correlation coefficients show that all the lipids tend to be elevated together, but these changes do not correlate with hyperuricaemia. The uric acid ratio was calculated and was of no value in detecting cerebral atherosclerotic disease. The significance of these findings is discussed.

We are indebted to Mr. J. Parks and Mr. J. P. Hall for the estimations of plasma lipids in the department of biochemistry. We are most grateful to Mr. E. Miller for statistical studies and for access to the computer.

\section{REFERENCES}

Albrink, M. J., Meigs, J. W., and Man, E. B. (1961). Serum lipids, hypertension, and coronary artery disease. Amer. J. Med., 31, 4-23.

(1962). Triglycerides, lipoproteins, and coronary artery disease. Arch. intern. Med., 109, 345-359.

Bauer, W., and Klemperer, F. (1947). Gout, pp. 611-656 in Diseases of Metabolism, 2nd Edn. Edited by G. G. Duncan. Saunders: Philadelphia.

Feldman, R. G., and Albrink, M. J. (1964). Serum lipids and cerebrovascular disease. Arch. Neurol. (Chic.), 10,91-100.

Fredrickson, D. S., Levy, R. I., and Lees, R. S. (1967). Fat transport in lipoproteins-an integrated approach to mechanisms and disorders. New Engl. J. Med., 276, 215-225.

Gertler, M. M., Garn, S. M., and Levine, S. A. (1951). Serum uric acid in relation to age and physique in health and in coronary heart disease. Ann. intern. Med., 34, 1421-1431.

Harris-Jones, J. N. (1957). Hyperuricaemia and essential hypercholesterolaemia. Lancet, 1, 857-860.

Heyman, A., Nefzger, M. D., and Estes, E. H. (1961). Serum cholesterol level in cerebral infarction. Arch. Neurol. (Chic.), 5, 264-268.

Jakobson, T. (1967). Glucose tolerance and serum lipid levels in patients with cerebrovascular disease. Acta med. scand., 182, 233-243.

Katsuki, S., Uzawa, H., Fujimi, S., Shiratsuchi, K., and Ito, Y. (1964). Studies on blood lipids in cases with cerebrovascular diseases, a preliminary report Jap. Heart J., 5, 101-107.

Meyer, J. S., Waltz, A. G., Hess, J. W., and Zak, B. (1959). Serum lipid and cholesterol levels in cerebrovascular disease. Arch. Neurol. (Chic.), 1, 303-311.

McDonald, I. W., and Hall, R. J. (1957). The conversion of casein into microbial proteins in the rumen. Biochem. J., 67, 400-405.

Oliver, M. F. (1968). Personal communication.

Pearce, J., and Aziz, H. (1969) Uric acids and plasma lipids in cerebrovascular disease. Part 1. Prevalence of hyperuricaemia. Brit. med. J., 4, 78-80.

Pearce, J., and Aziz, H. (1969). Prevalence of hyperuricaemia in cerebrovascular disease. Brit. med.J. (In press).

Peters, J. P., and Van Slyke, D. D. (1946). Quantitative Clinical Chemistry, 2nd Edn. Vol. I, part I, p. 1041. Williams and Wilkins: Baltimore, Md.

Robinson, R. W., Higano, N., and Cohen, W. D. (1963). Comparison of serum lipid levels in patients with cerebral thrombosis and in normal subjects. Ann. intern. Med., 59, 180-185.

Schrade, W., Boehle, E., and Biegler, R. (1960). Humoral changes in arteriosclerosis. Investigations on lipids, fatty acids, ketone bodies, pyruvic acid, lactic acid, and glucose in the blood. Lancet, 2, 1409-1416.

Van Handel, E., Zilversmit, D. B., and Bowman, K. (1957). Micromethod for the direct determination of serum triglycerides. J. Lab. clin. Med., 50, 152-157. 